\title{
RETRACTION
}

Korean J Intern Med 2017;32:211

https://doi.org/10.3904/kjim.2016.425

\section{Hepatic hydatid cyst}

Keum Nahn Jee

Department of Radiology, Dankook University Hospital, Cheonan, Korea

\author{
Korean J Intern Med 2015;30:554-555 \\ http://dx.doi.org/10.3904/kjim.2015.30.4.554
}

This article has been retracted following a review by the Editorial Board. It was found to be the same case with the published article, "Daughter cysts in a cyst of the liver: hepatic echinococcosis," by Kwon et al. [1] (Korean J Intern Med 2016;31:197-198). Therefore, the article by Jee [2] was decided to be retracted.

We apologize for any inconvenience that this may have caused.

\section{REFERENCES}

1. Kwon BW, Park SJ, Kong JH, Song IH. Daughter cysts in a cyst of the liver: hepatic echinococcosis. Korean J Intern Med 2016;31:197-198.

2. Jee KN. Hepatic hydatid cyst. Korean J Intern Med 2015;30:554-555. 